\title{
ANALYZING IMPLICATURES IN TALIWANG DIALECT
}

\author{
Ismiati \\ Faculty of Teacher Training and Education, Cordova University, Indonesia \\ Corresponding Author Email: ismiatisumarlin08@gmail.com
}

\begin{tabular}{|c|c|}
\hline Article Info & Abstract \\
\hline $\begin{array}{l}\text { Article History } \\
\text { Received: September } 2021 \\
\text { Revised: October } 2021 \\
\text { Published: October } 2021\end{array}$ & $\begin{array}{l}\text { This study aims to analyze the types of implicature and flouting maxims and the } \\
\text { reasons for doing the flouting in Taliwang Dialect. It applied the descriptive method } \\
\text { with a qualitative approach. Data was collected by recording natural conversations } \\
\text { among the natives of Taliwang Dialect. It was found two types of implicature, }\end{array}$ \\
\hline $\begin{array}{l}\text { Keywords } \\
\text { Implicature; } \\
\text { Taliwang Dialect }\end{array}$ & $\begin{array}{l}\text { namely, Generalized Conversational Implicature (GCI) and Particularized } \\
\text { Conversational Implicatures (PCI). In GCI, the speaker and interlocutor could } \\
\text { easily understand the conveyed utterances because they mostly used general } \\
\text { statements which are commonly spoken in the Taliwang dialect. In PCI, both } \\
\text { speaker and the interlocutor needed a particular knowledge to understand each } \\
\text { other because of the flouting maxim. Some speakers or hearers in PCI often break } \\
\text { the maxim in a conversation due to some reasons such as accepting untrue or lie } \\
\text { information, receiving more information than the needed information, getting } \\
\text { irrelevant information and having unclear or ambiguous information. }\end{array}$ \\
\hline
\end{tabular}

How to cite: Ismiati. (2021). Analyzing Implicatures In Taliwang Dialect, JOLLT Journal of Languages and Language Teaching, 9(4), pp. 432-441. DOI: https://doi.org/10.33394/jollt.v\%vi\%i.4215

\section{INTRODUCTION}

One of the pragmatic aspects often found in daily social conversation is implicature. The notion of implicature was first introduced by Grice (1967), who defines implicature as anything that was inferred from an utterance but that was not a condition for the truth of utterance. One type of implicature is conversational implicature to which this study is focused. In pragmatic, conversational implicature is described as an indirect speech act (Gargesh \& Sharma, 2019). It means that speakers who involve in conversation produce the implicit meaning of what they said. Conversational implicatures become parts of communication that describe the speakers' communicative intention is not exactly agreed to what speakers directly uttered (McConachy \& Hata, 2013; Chan, 2019).

Grice (1975) introduced two types of conversational implicature, which are generalized implicature and particularized implicature. Generalized implicature was a conversational implicature that is inferable without reference to any special context. Particularized implicature is conversational implicature that was derivable only in specific context. People need to do good communication to avoid offenses. Both speakers and listeners have to do cooperatively and mutually communicate in other they can understand each other. Paul Grice (1975) proposes cooperative principles which describe how effective communication is accepted in social interaction and how speakers' utterances are managed to be understood by hearers. Those principles are maxim of quality, maxim of quantity, maxim of relevance, and maxim of manner (Alhasibnur, 2018; Fahmi, 2018).

In fact, for a particular communicative purpose, implicature may break the maxims as the effective principles of communication. They're often found a violation to the maxim in the practice of daily social conversation. This violation is called flouting of maxim. It can be assumed that flouting maxims is a kind of violation that is deliberately committed by the speaker or the hearer for a specific reason. 
Regarding to the issue, this study intended to identify and analyze the types of implicature and flouting which occurred in sumbawanese daily conversation in the dialect of Taliwang. Sumbawa language is one of the vernacular languages in West Nusa Tenggara Province. Mahsun (1995) found that there are four dialects in Sumbawa, those are Jereweh dialect, Taliwang dialect, Tongo dialect, and Sumbawa Besar dialect. This study focuses to the dialect of Taliwang.

\section{RESEARCH METHOD}

This study applied a descriptive qualitative approach. Data was collected from recorded conversations. It was ten conversations naturally conducted by the native speakers of Taliwang dialect. The conversations set was concerned with family members, neighborhoods in which the researcher was involved as participants and non-participant observer. The first step of collected data was done through observation and recording the conversations.

\section{Research Design}

This study is a descriptive study that applies a qualitative approach. Descriptive study is one of the research methods which deeply describes the characteristics of the population being studied. The qualitative approach involves non-numerical Data. This approach intends to study people's experiences about the world. This study intends to analyze the social's experience in the use of implicature in their daily conversations. The subject of this study is conversations that naturally occurred in Taliwang Dialects. The number of selected conversations was ten. The conversations were purposively recorded. The instrument used in this study was a recording device and observation sheet.

\section{Data Analysis}

The content of utterances in the conversations was displayed and transcribed into a form of script. The transcription data was then reduced to find the implicatures. The finding implicature from the ten conversations was analyzed to identify the types of implicatures and flouting of maxim. At last, those types of implicature and flouting maxim were clearly presented and described to draw more detailed conclusions refers to the needs of this study.

\section{RESEARCH FINDINGS AND DISCUSSION Research Findings}

The data of this study consist of types of implicature and flouting maxim in Taliwang dialect. The analysis was carried out with reading and listening Taliwang dialect in conversation. The findings can be presented in Table 1 .

Table. 1

Types of implicature and flouting Maxim

\begin{tabular}{llll}
\hline No & Types of Implicature & Types Flouting of Maxim & Reasons of flouting maxim \\
\hline 1 & $\begin{array}{l}\text { Generalized } \\
\text { Conversational } \\
\text { Implicature (GCI) }\end{array}$ & flouting maxim of quality & $\begin{array}{l}\text { Accepting untrue } \\
\text { information }\end{array}$ \\
\hline 2 & $\begin{array}{l}\text { Particularized } \\
\text { Conversational } \\
\text { Implicatures (PCI) }\end{array}$ & Flouting maxim of quantity & $\begin{array}{l}\text { Receiving more information } \\
\text { than the needed information }\end{array}$ \\
\hline 3 & - & flouting maxim of relevance & Getting irrelevant information \\
\hline 4 & - & flouting maxim of manner & $\begin{array}{l}\text { Having unclear or ambiguity } \\
\text { information. }\end{array}$ \\
\hline
\end{tabular}

The table above shows there are only two types of implicature in Taliwang dialect conversations namely Generalized Conversational Implicature (GCI) and Particularized Conversational Implicatures (PCI). And four types of flouting maxim namely flouting maxim 
of quality, Flouting maxim of quantity, flouting maxim of relevance, and flouting maxim of manner. each flouting of maxim in the conversations occurred because of some reasons such as accepting untrue lie information, receiving more information than the needed information, getting irrelevant information, and having unclear or ambiguity information.

\section{Discussion}

\section{Types of Implicatures in Taliwang Dialect Conversations}

Implicature implied hidden utterances which can be expressed in polite and impolite ways with direct and indirect speech acts. In this case, the implicature is commonly deliberately occur rather than naturally. These types of implicature were found in Taliwang Dialect daily conversations. Those implicatures were deliberated with certain implied meaning during the process of conveying messages through the speakers' utterances. There were two types of implicature found in Taliwang Dialect conversations. Those are explained as follows:

\section{Generalized Conversational Implicature (GCI)}

Grice in Levinson (1992:126) asserts that Generalized Conversational Implicature (GCI) was implicature that arise without any particular context or special scenario being necessary. As can be seen in the following short conversation:

Conversation 1 (Voice...)

Speaker A: Kam datang Santi ke Riska antat uang ke?

Did Santi and Riska come to give money?

\section{Speaker B: Beru ka Riska datang}

Just Riska

The conversation occurred between two cousins in enjoyable place and time. Speaker A speaker B in the conversation naturally talked without any specific context. They discussed about various things include about the plan of social gathering. In this situation, speaker A noted for everyone who has already paid for the event. Both speakers actually asked and gave information about the name of people who had not collected money for a social gathering event. Speaker A asked to speaker B by saying "Kam datang Santi ke Liska antat uang ke?" (Did Santi and Liska come to give money?)". The speaker A's utterance indicated that she needed information whether Santi and Liska had paid for the event. Speaker B as the listener in the conversation gave direct responded by saying "beru ka liska (just Liska)". The utterance from speaker B indicated that the speaker B intended to give information that Santi had not paid for the event.

The implicature which occurred in the conversation was asserted as Generalized Conversational Imlicature (GCI) as the two speakers could easily understand one another. The utterance from speaker B can be easily understood by speaker A without needed any specific knowledge background to understand what speaker B intended to convey. By mentioning only one name of people by speaker B, the speaker A could used her general understanding to conclude that Santi had not paid yet. .

In another side, speaker B also did not need a particular knowledge to follow information that speaker A required. The literal meaning of the Sumbawanese language phrase "antat uang ke' which was uttered by speaker A is giving money to someone for a particular purpose. The statement was contextually interpreted and understood by speaker A that she needs to know whether whether Santi and liska had paid for the plan of social gathering event.

Conversation 2. (voice...)

Speaker A : Lo mpa' ke?

Do have something to eat? 


\section{Speaker B : So mpa' mangan mo!}

\section{Here you are you can eat!}

Speaker A and speaker B are both sisters. They did a conversation in the kitchen. Speaker A naturally asked B by saying "Lo mpa' ke?"(Do you have something to eat?). the speaker A's statement was categorized as GCI because in the case of Sumbawanes language, Taliwang dialect, the statement is interpreted that the speaker wanted to eat something instead of actually needed fish for eating. The statement can be easily understood by speaker B as the interlocutor in that context. Speaker B did not need any particular knowledge to get what the speaker intended to convey. As stated by a linguist that Generalized Conversational Implicature was type in which the interlocutors did not require special knowledge to know the meaning of a conversation because the context used in this type was a general conversation that makes an interlocutor directly understand the meaning of the conversation.

The literal meaning of the phrase "Lo mpa' ke?" which was uttered y speaker A was 'is there fish?. In the context of the conversation above, speaker B as the interlocutors who heard the speaker A's utterance could directly understand that speaker A did not refer her utterance to any names of fish or she was looking for fish to eat, however, speaker B used her general knowledge to understand that speaker A wanted to have lunch or she knows if speaker A was hungry. B's general understanding to the speaker A's Utterance can be seen from speaker B' respond which was said "So mpa' mangan mo!" (Here you are you can eat!). The utterance from $\mathrm{B}$ is indicated that she directly gave something for her sister to eat.

\section{Particularized Conversational Implicature (PCI)}

The particularized conversational implicature has been calculated without special knowledge of any particular context. It means that the interlocutor needs particular knowledge to understand what the speakers intended to convey because the utterances that speakers use was not naturally used in general context. This type of conversation was found in Taliwang dialect conversation such as in the short following talks:

Conversation 1: (Voice...)

Speaker A : Nime token kam beli lamung anak mu?

Where did you buy your children's clothes?

Speaker B : Token tau jual sendal

At shoes shop

The conversation took place in the porch of speaker A's house. Speaker A and speaker $\mathrm{B}$ are cousins. They talked about shopping. This types of conversation is categorized as Particularized Conversational Implicature (PCI) because it occurred in a specific context. Both speakers have discussed about a particular topic and the interlocutor needed a specific knowledge to understand the speaker' conveyed meaning. In the case of the conversation above, speaker B' utterance was categorized to PCI because the implied statement from speaker B was not general in context. Speaker A needs a specific understanding to the utterance.

In the conversation, Speaker A needs a specific information about the place of buying the cloths by saying "Nime token kam beli lamung anak mu?(where did you buy your children's clothes?). Speaker A wanted to know the name of shop where the cloth was bought and might be additional information about the price to be recommendation for her interest to by the same thing at the same place.

Speaker B' respond was less informative to what the speaker A intended to know. The speaker B said token tau jual sendal' (at the shoes shop). To understand the speaker B's utterance, Speaker A actually has to draw some assumed knowledge that speaker B bought her children's cloth at the online shop or at market because speaker B did not mention the name of place where the cloth was bought. 
The utterance from speaker B was still ambiguous which means that she did not give clear information about the name of shop where the cloth was bought. Therefore speaker A might need more information to know which shop the speaker B referred to.

Conversation 2:

Speaker A : Kam suda ke?

Have you finished?

Speaker B : Beru'sai

just already finished one

Speaker A : Be pia?

So, How many?

Speaker B : Minimal dua atau telu

Minimum, two or three

The conversation occurred in situation in which Speaker A and speaker B were sitting together in the living room. Both of the speakers are a mother and her daughter. They talked about a thesis writing which has been conducting by speaker B as the daughter of speaker A. The context of situation shows that speaker A showed her attention to her daughter project by asking the progress of her written work. Speaker A said 'kam suda ke?" (have you finished?). In this case, the mother intended to give support for her daughter in other she can build her motivation to finish her written work on time. Speaker B gave indirectly answer by saying 'Beru sai'(just already finished one) to mean that she had not finished yet. This utterance indicated a hidden meaning that speaker B intended to convey that she had not finished the written project yet. The speaker B's utterance shows a hidden context which need more clearly explanation to be understood by speaker A or influence the appearances of many other questions to ask clarification about the speaker B's respond. Speaker B implied specific context that she has done only a little by saying "beru' sai" or she had not completed the project yet. Speaker A then responded to ask clarification to what B said by saying "Be pia?" (So, How many?), in this case, Speaker A wanted to know more about the total numbers of speaker B' work and would like to know when speaker B would finish her project.

\section{Types and Reasons of Flouting Maxim}

Effective conversation describes cooperative principles to make the conversation contribution as what is required by both hearers and speakers. In the practice of daily naturally conversation, speakers and hearers may flout the maxims for any specific reasons or purposes. In particularized conversation, there often found violence of the maxim which is called flouting of maxims. In Taliwang dialect daily conversations, there found some types of flouting of maxim with each communicative reasons as follows:

\section{Flouting maxim of Quality}

In the practice of communication, particularly in daily conversation, people often break the maxim of quality by making flouting of quality. This flouting commonly occurs when the speaker says something untrue or the speaker tells lie which means he or she denies something that is believed to be false. The following were the example of flouting of quality.

Conversation 1: (voice..)

Speaker A : Nime token kam beli lamung anak mu?

Where do you buy your children's clothes?

Speaker B : Token tau jual sendal

At shoes shop

The conversation between speaker A and B took place at home. Speaker A and speaker B are both cousins. They enjoyed the talk about the places of shopping. Speaker A asked 
about the place of buying clothes to B. however, B gave untrue information. Speaker B told that the cloths were bought at shoes shops. In fact, they were bought in the cloths shop exactly at market.

In the conversation above, Speaker A intended to have true information about the place where the clothes were bought because she needs to buy the same. However, the information given by speaker B was not true and did not convey what speaker A needed to know. It can be seen the speaker B's utterance toward the conversation. "Token tau jual sendal" (At shoes shop) this kind of sentence contained implied meaning. Speaker B gave untrue information because in fact the cloths were not bought in at the shoes shop but at market. Speaker B should had said "Kak beli ning amat" (I bought in the market). In this case, speaker B' statement referred to flouting maxim of quality because speaker B conveyed untrue information because speaker A can assumed that B statement was not true because she mentioned shoes shop, it was contrary to the speaker A's question which need information about the name and the place of a cloth shop. It can be seen that speaker B did not provide information on the need of the speaker A. Flouting of Quantity

Flouting of quantity occurred when the speaker gives more or less information than required. The following were the examples of flouting of quantity.

Speaker A : Pia jadi nam beli punti ooo...?

How many bananas will you buy?

Speaker B : Sai bae mo

Just one

Speaker A : Nak isi dalam kresek ke?

Do I put it into plastic bag?

Speaker B : No ti nak kakan ningka

No, I will eat here

The conversation took place at market. Speaker A was a bananas trader and speaker B was a buyer who wanted to buy bananas. This case generating to PCI which occured in specific context. PCI stated in the speaker A's question. It can be seen the speaker A's utterance toward the conversation. Nak isi dalam kresek ke? (Do I put it into plastic bag?) this kind of sentence contained implied meaning which did not have any meaning. Actually speaker A did not need to ask this because normally when people buy a banana, the seller would directly put it into a plactic bag. In this case, the bold type utterance shows that the speaker $\mathrm{A}$ as the bananas seller did flouting of quantity because she presented information which was not required by speaker B as the buyer of the bananas.

As stated by Grundy (2000: 74) that maxim of quantity as one of the cooperative principles was concerned in giving the information as it was required and not giving the information more than it was required. The speakers just say the information needed, it should not be less informative or more informative. In the case of the above conversation, Speaker A' statement was less informative because her sentences did not give any information which the speaker B needed. Speaker A asked something that was excessive and not required by speaker B.

Speaker A : Bau terang ke lamin kam so penyakit tu?

can this disease be cured?

Speaker B : Lamin keman dunu-dunu ling tau penyakit sa nonya mido na, hanya bau tu bedoa bae can help)

(People said that there is no medicine for such disease, only prayer

The conversation occurred in a situation in which Speaker A and speaker B are sitting together in the living room. They were talking about someone who is stricken by dangerous 
disease. Speaker A and speaker B are both sisters. This conversation was generated as because it occurred in specific context and talked about a particular topic. In this case, speaker B did flouting maxim of quantity as it can be seen the speaker B's utterance toward the conversation.'

"Lamin keman dunu-dunu ling tau penyakit sa nonya mido na, hanya bau tu bedoa bae (People said that there is no medicine for such disease, only prayer can help) this kind of sentence contained implied meaning. Actually speaker B should cooperatively answer by to what was required. Speaker B should had said" No bau terang (Cannot recover)". Speaker B was considered to give more information did not actually needed by Speaker A. speaker A only needed to know whether or not the disease can be cured, not more than that. Speaker B only needed to answer 'No, it could not' in other to give clear answer. Speaker B did not need to produce additional or longer statements such as' (1) keman dunu-dunu (since long time), (2) ling tau (people said), (3) 'penyakit sa nonya mido (there is no medicine for this disease. Those utterances were considered more imperative which did not actually intended to know by speaker A.

\section{Flouting of Relevance}

Maxim of relevant means that the utterance from speakers have to be relevant to the topic of conversation. Flouting of relevance occurred when the response is obviously irrelevant to the topic (abrupt change of topic, overt failure to address interlocutor's goal in asking a question). In Sumbawa dialect daily conversations. People often flout the maxim of relevant for various reasons. The following conversation were the example of flouting of relevance which was found in Taliwang daily conversation:

Conversation 1: (Voice...)

Speaker A : Pusing aku sa pikir skripsi ku

I am confused thinking about my thesis writing

Speaker B : Be nuya kam mu lulus kuliah ke?

\section{You have finished your study, haven't you?}

Speaker A : Weh nopoka

Not yet (with upset intonation)

Context : Speaker A and speaker B were talking about the thesis, and speaker A feel confusion. Speaker A and speaker B are both friends. This case generating to PCI where occured in specific context. They talk about a thesis writing which became a particular topic of the conversation. The utterances from speaker B implied irrelevance information to speaker A' statement. Speaker A conveyed her confusing about her thesis writing by saying "Pusing aku sa pikir skripsi ku" (I am confused thinking about my thesis writing). Speaker A intended to have support or any suggestion from speaker B about her problems of her thesis. However, the respond from speaker B was not relevant to the statement from speaker A. speaker B should had said "do not too worry about it or it will be fine if you work hard and ask for help from others to complete your thesis writing". Speaker B should not said "Be nuya kam mu lulus kuliah ke? (You have finished your study, haven't you?). The bold type statement from speaker B indicated as flouting of relevance because it did not relevant to the information which was expected by speaker A. Grundy (2000: 74) states that maxim of relevance was fulfilled when the speaker give information that was relevant to the topic of conversation. Therefore, each of the speaker or hearer must be relevant to the topic of conversation.

Conversation 2 (voice...)

Speaker A : Lamin ku muli keman Mataram bau jemput ku ke?

If I come back from Mataram, can you pick me up?

Speaker B : Maya nam muli? berarti nam muli ke bis?

When will you come back? Do don't you gohome by bus? 


\author{
Speaker A : Iya, nar ke bis \\ Yes, I going by bus tomorrow
}

Speaker A and B are a mother and her daughter. They are talking about a particular topic which is considered as part of particularized conversational Implicature (PCI) because the conversation discussed about a specific thing. Speaker A went to a city and would like to came back to his hometown. He asked speaker B to pick him up by saying the utterance "Lamin ku muli keman Mataram bau jemput ku ke?( If I come back from Mataram, can you pick me up?). In this case, speaker A asking for help from speaker B to pick him up when he arrived at the bus station of their hometown. He intended to have speaker B's respond whether or not he would be able to pick him up. The respond from speaker B was not relevant to the information that speaker A required. Speaker B should had given relevant respond by saying " bau ti (yes I can), " no ku bau jemput mu" ( I cannot pick you), or ya mo, jam pia nak jemput mu? (It's okay, what time do I pick you up?) instead of saying "Maya nam muli? berarti nam muli? (When will you come back? Do don't you go home by bus?). The bold type statement was described as irrelevant information because it creates a new question for speaker A, in fact, speaker A needed direct and relevant answer of his questions. However speaker B did not give answer for speaker A' question, but asking back to speaker A.

Conversation 3: (Voice...)

Speaker A : Kam uba hp?

Do you bring your hand phone?

Speaker B : Nonya pulsa

No, I don't have any phone credit

Speaker A : Patik hp nonya pulsa

Do you have a phone but have not pulse

The conversation occurred at a market. Speaker A and speaker B are two friends. Context : Such conversation occurred in the market. Speaker A wanted to borrow speaker B's hand phone to call her husband. Speaker A said "kam uba HP? (do you bring your hand phone? The statement indicated that speaker A needed to borrow speaker B' $\mathrm{s}$ hand phone. Speaker B responded the statement from speaker A by saying "Nonya pulsa" (I don't have any phone credit). The statement described that speaker B did flouting of maxim relevance because speaker B presented irrelevant information for speaker A. She answered the question from speaker A with a statement which did not required by speaker A. To give relevant respond to speaker A's question, speaker B should had said "nongka ku uba HP ku" (I don't bring my hand phone.

\title{
Flouting of Manner
}

Maxim of manner refers to the way speakers cooperate in a conversation by presenting or saying clear, brief, and orderly statements and avoid obscurity and ambiguity in their sentences. In fact, in the practice of natural daily conversation in social life, many people often break the maxim of manner in the ways that the maxim was not brief, the speaker use obscure language, the speaker' statements was not orderly or and often use ambiguity statements. The speakers commonly use ambiguity and obscurity statements for certain reasons. Some speakers used such statements to convey important information which can only addressed to a certain group of people. Other people talk ambiguously with intentions to give negative impression to a certain things.

The use of unclear statement was considered as the practice of Flouting of manner. it can be seen in the conversation below: 


\section{Speaker A : Sia buya punti ke? are you looking for bananas? \\ Speaker B : Ee, ku buya punti seribu Yes, I'm looking for punti seribu \\ Speaker A : Deh! be nonya punti murah Wow! No cheap price for bananas}

The conversation between speaker A and speaker B took place at a market. Speaker A was a fruits seller and speaker B was a buyer. When the speaker B approached the speaker B, the talk among them naturally occurred. The conversation was categorized as PCI as it occurred in specific context, with a particular topic and at a specific place where only a certain activity can be occurred. Speaker A as the seller talked firstly to greet the speaker B as the buyer.

Speaker A as the seller said to speaker B "sia buya punti ke? (are you looking for bananas?. The statement or question from speaker A can be explained that speaker A asked speaker B weather she looked for and wanted to buy bananas. Speaker B responded to speaker A's question by uttering" Ee, $\boldsymbol{k}$ u buya 'punti seribu' (Yes, I'm looking for 'Punti seribu'). In this case, 'punti seribu' means a name for banana. Speaker B' said 'punti seribu' to refer to one of banana's namaes. The speaker B' s statement was misinterpreted by speaker A. in speaker A's mind, 'punti seribu' means the cheap price of the banana. It can be seen from speaker A's respond to speaker B's statement by saying' Deh! be nonya punti mura (Wow! No cheap price for bananas). The statement from speaker A can be interpreted that speaker A informed that the buyer, speaker B cannot find cheap price of banana. 'punti seribu'. In sumbawanese language means the banana price was one thousand. 'punti' means banana 'seribu' means one thousand rupiah. One thousand rupiah for buying banana was considered too cheap because in fact the normal price of banana at the market was thirty thousand rupiah or minimum ten thousand rupiah.

In the case of B' statement in the short conversation, it can be explained that speaker B did flouting of manner, because she broke the conversational maxim of manner which needed to be cooperatively presented in its ways when people practice the conversation. Speakers would consider cooperative to practice maxim of manner if they produced clear statement and avoided ambiguity interpretation from the hearers. In the conversation above, Speaker B' statement was misunderstood by speaker A because the speaker B presented ambiguity statement. Speaker B should had said 'Ee, ku buya punti singen punti seribu' (Yes, I'm looking for bananas named punti seribu). To avoid misunderstanding by speaker A, speaker B should had clearly mentioned that the word 'punti seribu' refers to the name of banana not the price of the banana to make clear statement for speaker A. Speaker B should had not said' ku buya punti seribu' because the words 'punti seribu" not only mean the name of banana as speaker B intended to convey, but also it can refer to the cheap price of banana as what had been interpreted by speaker A. speaker A understood the words as the price of one thousand and one thousand rupiah was considered as a cheap price. Speaker B should had clearly told speaker A that 'punti seribu' in her mind was the name of banana which she intended to buy.

\section{CONCLUSION}

This study found 20 implicatures which were classified into two types namely Generalized conversational implicature (GCI) and particularized conversational implicatures (PCI). There were four types of flouting maxim namely flouting maxim of quality, maxim of quantity, flouting maxim of relevance, and flouting maxim of manner. Some speakers or hearers in PCI often break the maxim in a conversation because of some reasons such as 
Accepting untrue lie information, receiving more information than the needed information, getting irrelevant information, and having unclear or ambiguity information.

\section{ACKNOWLEDGEMENT}

I would like to express my gratitude to all people who support within the whole process of this study.

\section{REFERENCES}

Alhasibunur, A. (2018). The Analysis of Morphological Process of Students' English Utterances. Journal of Languages and Language Teaching, 4(2), 47-54. doi: https://doi.org/10.33394/jollt.v4i2.316

Arikunto, S. (2002). Prosedur PenelitianSuatu Pendekatan Praktek. Jakarta: Rineka Cipta.

Arikunto, S. (2009). Manajemen Penelitian. Jakarta: Rineka Cipta.

Brown, G. \& Yule, G. (1989). Discourse Analysis. Cambridge: Cambridge University.

Chan, J. Y. H. (2019). The choice of English pronunciation goals: different views, experiences and concerns of students, teachers and professionals. Asian Englishes, 21(3), 264-284. https://doi.org/10.1080/13488678.2018.1482436

Fahmi, R. (2018). An Analysis of Grice's Maxims Violation in Daily Conversation. Journal of Languages and Language Teaching, 4(2), 91-97. doi: https://doi.org/10.33394/jollt.v4i2.325

Gargesh, R., \& Sharma, A. (2019). Indian English in political discussions. World Englishes, 38(1-2), 90-104. https://doi.org/10.1111/weng.12394

Grice. H. P. (1967). William James Lecture Series. Boston: Harvard University

Press.

Grice, H.P. (1975). Logic and Conversation. New York: Oxford University Press.

Grundy, P. (2000). Doing Pragmatics. London: Hodder Arnold Publication.

Hadiyanto, T., \& Makinuddin. (2006). Analisis Sosial. Bandung: Yayasan Akatiga.

Lakoff, G. (1993). The Contemporary Theory of Metaphor. Cambridge: Cambridge University Press.

Lee, J. S. (2020). Digital communication, social media, and Englishes. World Englishes, 39(1), 2-6. https://doi.org/10.1111/weng.12447

Levinson, S.C. (1983). Pragmatics. London: Cambridge University Press.

Mahsun. (1994). Penelitian Dialek Geografi Bahasa Sumbawa Yogyakarta: Tesis S3 Universitas Gadjah Mada.

McConachy, T., \& Hata, K. (2013). Addressing textbook representations of pragmatics and culture. ELT Journal, 67(3), 294-301. https://doi.org/10.1093/elt/cct017

Miles, M.B. \& Huberman, A.M. (1994). Qualitative Data Analysis. London: Sage Publishers.

Paltridge, B. (2000). Making Sense Of Discourse Analysis. Queensland: Gerd Stabler.

Paltridge, B. (2006). Discourse Analysis.: An Introduction. London \& New York: Continuum.

Saragi, Y.M. (2011). Flouting Maxims in Conversational Implicature in the Ellen Degenerates Talk Show. Surabaya: State University of Surabaya.

Searle, R. J. (1975). Speech Acts and Recent Linguictics. Cambridge: Cambridge University Press.

Tannen, D. (2005). Conversational Style: Analysisn Talk Among Friends. New Jersey: Alex Publishing Corporation Norwood.

Yule, G. (2006). The Study of Language. New York: Cambridge University Press.

Yule, G. (1996). Pragmatics. Oxford: Oxford University Press. 